\title{
Detection of Mycoplasma gallisepticum and Mycoplasma synoviae by using of cultural and PCR technique
}

\author{
N.A. Jafar and B.S. Noomi* \\ Department of Microbiology, College of Veterinary Medicine, Tikrit University, Tikrit, Iraq \\ *Email: vetbashar1981@gmail.com
}

(Received December 18, 2018; Accepted March 15, 2019)

\begin{abstract}
Laboratory methods are essential for the diagnosis of Mycoplasmal infection. There are three laboratory approaches are essential for the diagnosis of Mycoplasmal infection in chicken including direct methods by culture method and polymerase chain reaction, and indirect methods by detection of Mycoplasmal antibodies by serological tests. This study aimed to detection of Mycoplasma by culture and PCR technique. Two hundred seventy-six samples were collected from infected adult boiler chicken in Salah Al-din province which suffering from respiratory signs and /or joint infection, 202 respiratory and 74 articular samples. According to the results of culture, Mycoplasma isolated in rate of 35.1\% (36.6\% from respiratory samples and $31.1 \%$ from articular samples). The sensitivity of culture was $100 \%$, while the specificity of culture was $97.9 \%$ when comparing with PCR results. The current study concluded that the respiratory infection was more than articular infections, and Mycoplasma gallisepticum more distributed than Mycoplasma synoviae among chickens.
\end{abstract}

Keywords: Mycoplasma gallisepticum, Mycoplasma synoviae, PCR, Culture

Available online at http://www.vetmedmosul.com



الخلاصة

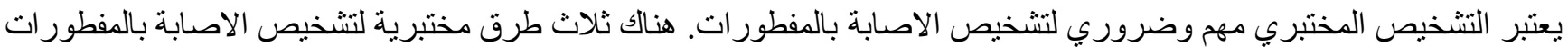

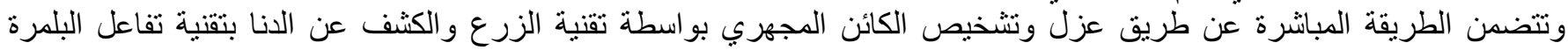

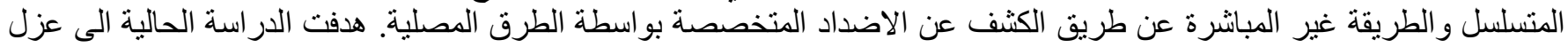

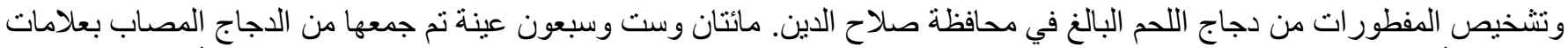

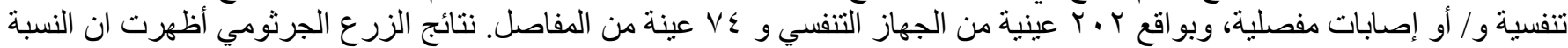

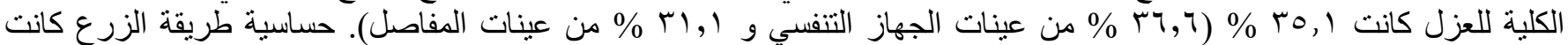

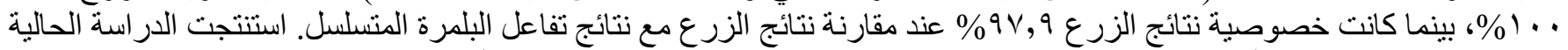

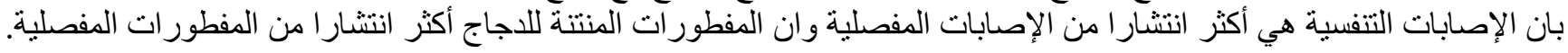

\section{Introduction}

Avian Mycoplasmosis are highly contagious disease of poultry. The first description of the disease was in turkey in
1926 and then described in chicken in $1936(1,2)$. Although there are more than 120 species, avian mycoplasmosis mainly caused by Mycoplasma gallisepticum (MG) and Mycoplasma synoviae (MS). The disease called chronic 
respiratory disease in chicken and infectious sinusitis in turkey $(3,4)$. It causes a highly economic loss by decreasing in hatching rate, exclude of infected Chicks, decrease in eggs production, reduced growth rate, increased costs of eradication procedures which involve site cleaning and depopulation, and increased costs of medication and vaccination $(5,6)$. Recurrent respiratory infection and bad environmental conditions considered as predisposing factors for Mycoplasmal infection (4,7). Avian Mycoplasmosis transmission occur horizontally through aerosols and vertically through the egg, leading to a rapid spread within the flock (8). The main clinical signs are: upper respiratory tract infection, sinusitis, coughing, sneezing, fluid secretion from nose and eye, bloody diarrhea, enlargement of joint and lameness $(3,9)$. Laboratory methods are essential for the diagnosis of Mycoplasmal infection, since, clinical signs and pathological lesions cannot reliably diagnose the source of infection. Rapid and early diagnostic detection of Mycoplasmal infections is important to prevent the spread of infection and to limit economic losses in the poultry industry. There are three approaches to diagnose mycoplasma infection: isolation and identification of organism by culture techniques, detection of its DNA, and identification of specific antibodies by serological methods like ELISA, serum plate agglutination test, and hemagglutination inhibition test (10-12).

The aim of the current study was to determine mycoplasma prevalence ratio in suspected chicken and evaluation of mycoplasma diagnostic methods used in poultry.

\section{Materials and methods}

\section{Samples collection}

276 samples (202 tracheal or air sac samples and 74 articular samples) collected from infected adult boiler chicken suffering from respiratory signs and /or joint infection. The samples which were taken in the present study include; tracheal samples: collected by using of sterile cotton swabs, or part of trachea after postmortem, articular samples: collected by either synovial fluid by using of sterile syringes or whole joint after postmortem, air sac samples: collected by taking part of air sac after postmortem.

\section{Culture methods}

All samples were cultured in Freyś broth medium with additives which included $150 \mathrm{ml}$ horse serum collected from jugular vein, then centrifuged and filtrated by using $0.22 \mu \mathrm{m}$ mellipore, $100 \mathrm{ml}$ of yeast extract prepared according to Kleven (13), $5 \mathrm{ml}$ of cysteine hydrochloride (Himedia- India), $5 \mathrm{ml}$ of NAD (Himedia- India $(0.1 \mathrm{~g}: 5 \mathrm{ml})$, $20 \mathrm{ml}$ of Thallium acetate $(1 \mathrm{~g}: 100 \mathrm{ml}), 5 \mathrm{ml}$ of penicillin solution (1,000,000 I.U.) (Segmi), $10 \mathrm{ml}$ dextrose (50 $\mathrm{gm}: 100 \mathrm{ml})$, and $10 \mathrm{ml}$ phenol red $(1 \mathrm{~g}: 100 \mathrm{ml})$. The final $\mathrm{pH}$ adjusted to 8.9 , then the broth incubated with $5-10 \% \mathrm{CO}_{2}$ at $37 \mathrm{C}$ for 2 weeks. Presence of turbidity or color conversion from red to yellow refer to Mycoplasma growing (13). 100 $\mu l$ of Freyś broth medium were cultured on two Freyś agar media (Oxoid, England) with the same additive expect phenol red. One agar with NAD (for isolation of MS) and other without NAD (for isolation of MG), then incubated with $5-10 \% \mathrm{CO}_{2}$ at $37 \mathrm{C}^{\circ}$ and examined after 3 days. The appearing of fried eggs colony under dissecting microscope refer to positive result (13).

\section{Genetic methods}

DNA extraction: DNA template was prepared by thermal methods and according to (11).

A single colony was taken and dissolved in $100 \mu \mathrm{m} 1$ of distilled water, then centrifuged to discard the remaining culture media, supernatant was discarded then $100 \mu \mathrm{l}$ of distilled water were re-added and heated at $100 \mathrm{C}^{\circ}$ for 10 mints, then centrifuged $(1400 \mathrm{~g} / \mathrm{M})$ for five minutes, supernatant was taken which contain DNA and kept at -20 ${ }^{\circ} \mathrm{C}$.

Reaction mixture consist of $0.5 \mu$ of Primer F $(20 \mathrm{p}$ mole $/ \mu \mathrm{l}), 0.5 \mu \mathrm{l}$ Primer R (20 p mole $/ \mu \mathrm{l}), 0.25 \mu \mathrm{l}$ of Taq Polymerase, $1 \mu \mathrm{dNTP}, 2 \mu \mathrm{l}$ of $\mathrm{MgCl} 2,5 \mu \mathrm{l}$ of $10 \mathrm{x}$ PCR Buffer and $35.75 \mu \mathrm{l}$ of distilled water

Thermocycler program: include 35 cycles, cycle steps temperature was as follows: $94^{\circ} \mathrm{C}$ for 30 seconds in Denaturation step, $55^{\circ} \mathrm{C}$ for 30 seconds for Primerannealing, and $55^{\circ} \mathrm{C}$ for 1 mint. for DNA extension.

Table 1: Primers used in the current study

\begin{tabular}{ccccc}
\hline Primer & & Primer sequence & bp & Reference \\
\hline \multirow{2}{*}{ Mycoplasma gene } & $\mathrm{F}$ & 5-GGGAGCAAACAGGATTAGATACCCT3 & 270 & 9 \\
& $\mathrm{R}$ & 5-TGCACCATCTGTCACTCTGTTAACCTC-3 & & \multirow{2}{*}{10} \\
MS & $\mathrm{F}$ & 5'-GAGAAGCAAAATAGTGATATC-3' & 207 & \\
& $\mathrm{R}$ & 5'-CAGTCGTCTCCGTTAACAA-3' & & \multirow{2}{*}{ (1) } \\
\hline
\end{tabular}


Interpretation of the results: Positive and negative agreement, sensitivity and specificity, and positive and negative predictive value for each method were calculated according to the following equations:

Positive agreement

$=\frac{\text { No. of samples gave positive results in first test }}{\text { No. of samples gave positive results in second test }} \times 100$

Negative agreement

$=\frac{\text { No. of samples gave negative results in first test }}{\text { No. of samples gave negative results in second test }} \times 100$

Sensitivity $=\frac{\text { True positive }}{\text { True positive }+ \text { false negative }} \times 100$
Specificity $=\frac{\text { True negative }}{\text { True negative }+ \text { false positive }} \times 100$

Positive predictive values

$$
=\frac{\text { True positive }}{\text { True positive }+ \text { false positive }} \times 100
$$

Negative predictive values

$$
=\frac{\text { True negative }}{\text { True negative }+ \text { false negative }} \times 100
$$

\section{Results}

\section{Mycoplasma isolation}

The result of respiratory samples culture for Mycoplasma on Freyś agar showed that Mycoplasma isolated in rate of $36.6 \%$. High isolation rate recorded from tracheal samples which was $40.4 \%$ compared with air sac sample which was $23.9 \%$ (Table 2). The isolation rate of Mycoplasma from articular samples was about $31.1 \%$ (Tables 3).

Table 2: Mycoplasma isolation ratio from respiratory samples

\begin{tabular}{lccc}
\hline Types of samples & $\begin{array}{c}\text { No. of } \\
\text { samples }\end{array}$ & $\begin{array}{c}\text { No. of } \\
\text { positive cases }\end{array}$ & Rate \\
\hline Tracheal samples & 156 & 63 & $40.4 \%$ \\
Air sac sample & 46 & 11 & $23.9 \%$ \\
\hline Total & 202 & 74 & $36.6 \%$ \\
\hline
\end{tabular}

Table 3: Mycoplasma isolation ratio from articular samples

\begin{tabular}{lccc}
\hline Types of samples & $\begin{array}{c}\text { No. of } \\
\text { samples }\end{array}$ & $\begin{array}{c}\text { No. of } \\
\text { positive cases }\end{array}$ & Rate \\
\hline Total & 74 & 23 & $31.1 \%$ \\
\hline
\end{tabular}

\section{Classification of Mycoplasma isolates into MG and MS}

The Diagnosis of isolated Mycoplasma into species was done according to the DNA content of the isolated microorganisms by using of PCR. The results showed that the 97 isolates grown on Freyś agar (Figure 1) were belong to Mycoplasma genus, from those, 58 (59.8\%) were belong to MG and 39 (40.2) diagnosed as MS (Table 4). Also, from table 4 it is clear that all $23(100 \%)$ articulate samples diagnosed as MS, while respiratory samples showed that 58 (78.4\%) from total 74 respiratory isolates diagnosed as MG and $16(21.6 \%)$ were belong to MS species (Figures 2-4).

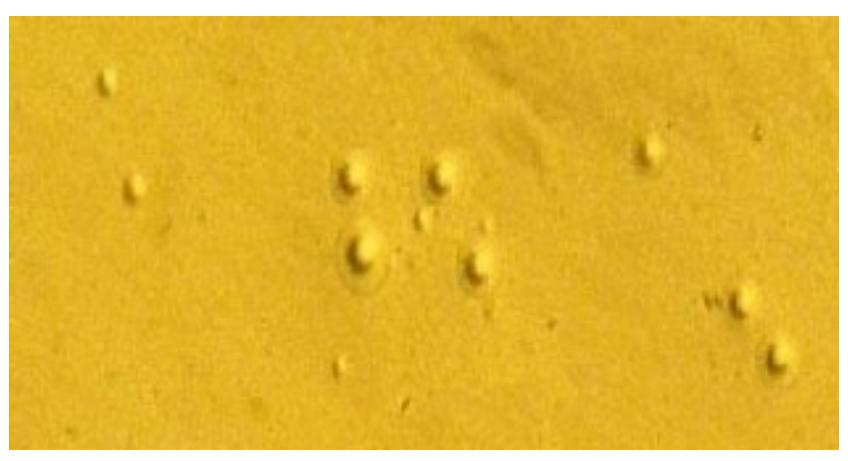

Figure 1: The colony of Mycoplasma spp. on Freyś agar.

Table 4: Classification of Mycoplasma isolates using PCR

\begin{tabular}{lccccc}
\hline \multirow{2}{*}{ Types of samples } & \multirow{2}{*}{ No } & \multicolumn{2}{c}{ MG } & \multicolumn{2}{c}{ MS } \\
\cline { 3 - 6 } & & No & Rate & No & Rate \\
\hline Respiratory isolates & 74 & 58 & $78.4 \%$ & 16 & $21.6 \%$ \\
Articular isolates & 23 & 0 & $0 \%$ & 23 & $100 \%$ \\
Total & 97 & 58 & $59.8 \%$ & 39 & $40.2 \%$ \\
\hline
\end{tabular}

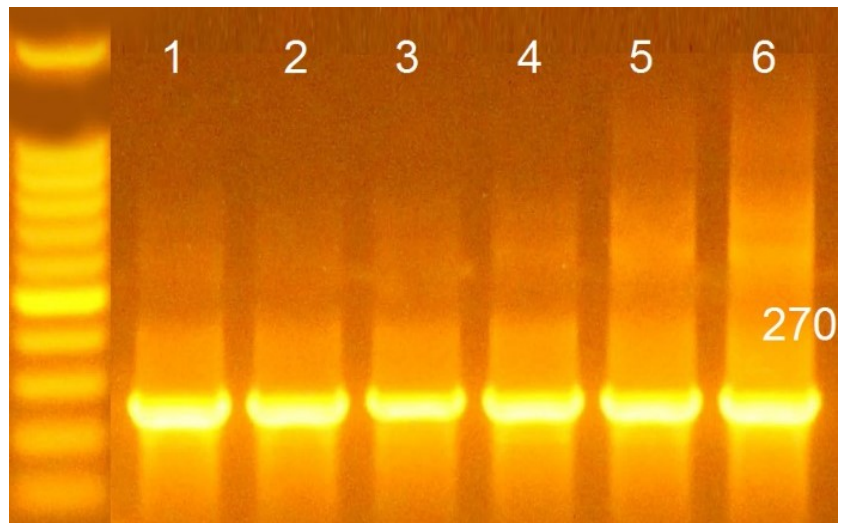

Figure 2: Electrophoresis on $2 \%$ agarose gel and ethidium bromide staining, showing the results of PCR procedures. M: DNA marker, wells 1-6 positive samples of Mycoplasma genus with band size $270 \mathrm{bp}$. 


\section{Comparison between the results of culture method and PCR for MG}

Table 5 showed that the sensitivity, specificity, positive predictive values and negative predictive values were: $100 \%, 89.7 \%, 72.4 \%$ and $100 \%$ respectively.

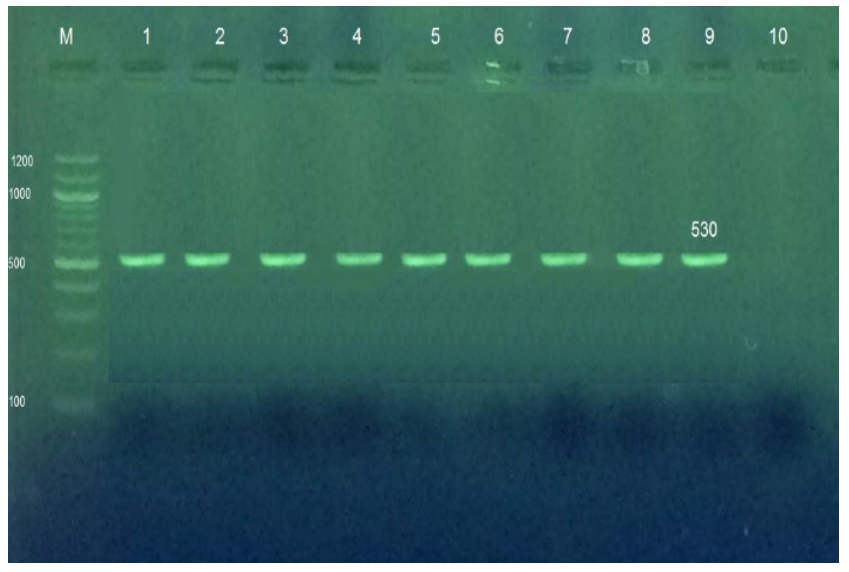

Figure 3: Electrophoresis on $2 \%$ agarose gel and ethidium bromide staining, showing the results of PCR procedures. M: DNA marker, wells 1-9 positive samples of Mycoplasma gallisepticum (MG), with band size $530 \mathrm{bp}$.

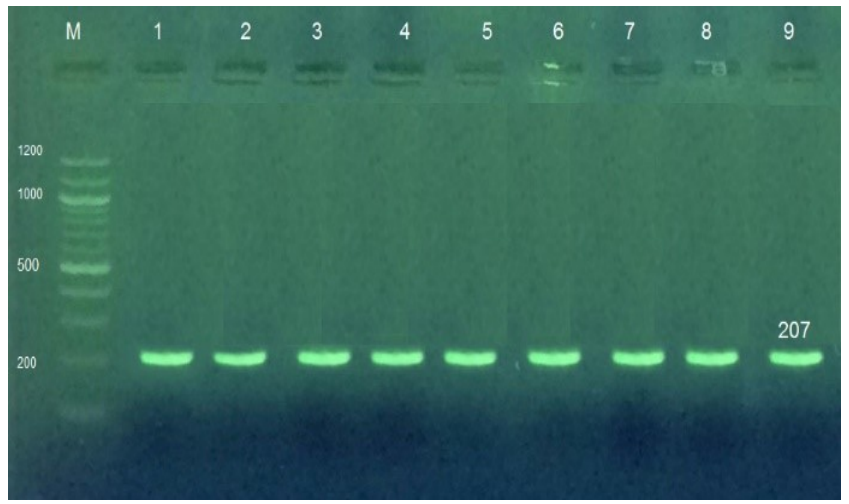

Figure 4: Electrophoresis on $2 \%$ agarose gel and ethidium bromide staining, showing the results of PCR procedures. M: DNA marker, wells 1-9 positive samples of Mycoplasma synoviae (MS) with band size $207 \mathrm{bp}$.

Table 5: Comparison between cultural and PCR method for the diagnosis of $\mathrm{MG}$

\begin{tabular}{|c|c|c|c|c|}
\hline \multirow{3}{*}{$\begin{array}{l}\text { Culture } \\
\text { Result }\end{array}$} & \multicolumn{3}{|c|}{ Result of PCR test } & \multirow{2}{*}{ Total } \\
\hline & Positive & Negative & & \\
\hline & True positive 42 & False positive & 16 & 58 \\
\hline & False negative 0 & True negative & 218 & 218 \\
\hline Total & 42 & & 234 & 276 \\
\hline
\end{tabular}

\section{Comparison between the results of culture method and PCR for MS}

From table 6 it is obvious that the sensitivity, specificity, positive predictive values and negative predictive values were: $100 \%, 97.9 \%, 87.1 \%$ and $100 \%$.

Table 6: Comparison between cultural and PCR method for the diagnosis of MS

\begin{tabular}{|c|c|c|c|c|c|}
\hline \multirow{3}{*}{$\begin{array}{l}\text { Culture } \\
\text { Result }\end{array}$} & \multicolumn{4}{|c|}{ Result of PCR test } & \multirow{2}{*}{ Total } \\
\hline & Positive & & Negative & & \\
\hline & True positive & 34 & False positive & 5 & 39 \\
\hline & False negative & 0 & True negative & 237 & 237 \\
\hline Total & & 34 & & 242 & 276 \\
\hline
\end{tabular}

\section{Discussion}

The direct diagnosis of the Mycoplasma can be carried out by either culturing the microorganism or detection of its DNA using PCR procedures (4). Detection of causative agent in Mycoplasma considered as gold stander in diagnosis because of that serological test unable to detect the subclinical and early infection $(3,4)$. Therefore, in the current study the culture and PCR methods were used as a basis for the diagnosis of Mycoplasma.

Mycoplasma isolated in rate of $35.1 \%$. This ratio is more than that recorded by (15) which was $25.7 \%$. That's may be due to difference in location of the study and different type of medium that was used and in additives. In regard to Mycoplasma species, the ratio of MG isolation was more than that of MS. Since, MG is the main cause of CRD and main important economically (4). The same results were recorded by other studies $(3,16)$. According to MS, in addition to its isolation from chickens suffering from articular signs, it was also isolated from respiratory infection cases. Therefore, it may cause sub-clinical infection, air saculitis and secondary respiratory infection (13).

When comparing between culture results and PCR test, the result showed that the sensitivity of culture was $100 \%$, while the specificity of the culture was $97.9 \%$. That is mean that some of the pathogen which were diagnosed as MG or MS were misdiagnosed and maybe belonging to other Mycoplasma species.

\section{References}

1. Nascimento ER, Pereira VL, Nascimento MG, and Barreto ML. Avian mycoplasmosis update. Brazilian J Poul Sci. 2005;7(1):1-9. doi.org/10.1590/S1516-635X2005000100001

2. Kleven SH. Control of avian mycoplasma infections in commercial poultry. Avi Dis. 2008;52:367-374.doi.org/10.1637/8323-041808Review.1 
3. International Office of Epizootics. Manual of diagnostic tests and vaccines for terrestrial animals: mammals, birds and bees. Stockholm: Office international des epizooties; 2008.

4. Ley DH. Mycoplasma gallisepticum Infection. In: Diseases of Poultry. Saif YM, Barnes JR, Glisson AM, Fadly LR editors. Diseases of Poultry. $11^{\text {th }}$ ed. Iowa: Iowa State Press; 2003. $722-744$ p.

5. Kleven SH, Rowland GN, and Kumar MC. Poor serologic response to upper respiratory infection with Mycoplasma synoviae in turkeys. Avi Dis. 2001;48:719-723.DOI: 10.2307/1592918

6. Levisohn S, Kleven SH. Avian mycoplasmosis (Mycoplasma gallisepticum). Revue Sci Tech Inter Epi. 2000;19(2):425-434.

7. Anderson DP, Wolfe RR, Cherms FL, Roper WE. Influence of dust and ammonia on the development of air sac lesions in turkeys. Am J Vet Res. 1968;29(5):1049.

8. Nascimento ER, Pereira VL. Mycoplasmosis. New York: Campinas; 2009. 485-500 p.

9. May M, Kleven SH, Brown DR. Sialidase activity in Mycoplasma synoviae. Avi Dis. 2007;51(4):829-833.doi: 10.1637/7806-120106REGR.1

10. Dufour L, Swayne DE, Glisson JR, Pearson JE, Reed WM, Jackwood MW, Woolcock PR. A laboratory manual for the isolation, identification and characterization of avian pathogens. $5^{\text {th }}$ ed. Athens: American Association of Avian Pathologists; 2008. 59-64 p.
11. OIE. Avian mycoplasmosis (Mycoplasma gallisepticum, Mycoplasma synoviae). OIE Terrestrial Manual; 2008. 525-541 p.

12. Qasem JA, Al-Mouqati SA, Al-Ali EM, Ben-Haji A. Application of molecular and serological methods for rapid detection of Mycoplasma gallisepticum infection (Avian mycoplasmosis). Pakistan J Biol Sci. 2015;18:81-87.DOI:10.3923/pjbs.2015.81.87

13. Kleven SH, Fan HH, Turner KS. Pen trial studies on the use of live vaccines to displace virulent Mycoplasma gallisepticum in chickens. Avi Dis. 1998;300-306.DOI: 10.2307/1592480

14. Allan WH, Gough RE. A standard hemagglutination inhibition test for Newcastle disease: A comparison of macro and micro methods. Vet Rec. 1974;95(6):120-123.DOI:10.1136/vr.95.6.120

15. Al-Dabhawe AH, Kadhim HM, Samaka HM. Molecular detection of infectious bronchitis virus and it is relation with avian influenza virus (H9) and Mycoplasma gallisepticum from different geographical regions in Iraq. Iraqi J Vet Sci. 2013;27(2):97-101. DOI:10.33899/ijvs.2013.82811

16. Mardassi BB, Mohamed RB, Gueriri I, Boughattas S, Mlik B. Duplex PCR to differentiate between Mycoplasma synoviae and Mycoplasma gallisepticum on the basis of conserved species-specific sequences of their hemagglutinin genes. J Clin Microbiol. 2005;43(2):948-958. DOI:10.1128/JCM.43.2.948-950.2005 